\title{
THE REGULATORY FRAMEWORK OF THE EUROPEAN UNION AND THE BANKING SECTOR OF THE REPUBLIC OF SERBIA
}

\author{
UDC 336.71(497.11:4-672EU)
}

\section{Edisa Brničanin ${ }^{1}$, Miloš Pavlović ${ }^{2}$ Nemanja Gligorijević ${ }^{3}$}

${ }^{1}$ State University of Novi Pazar, Department for Economy, Republic of Serbia ${ }^{2}$ Univerity of Priština, Faculty of Economics, Kosovska Mitrovica, Republic of Serbia ${ }^{3}$ Business Incubator Center Yumco DOO Vranje, Republic of Serbia

\begin{abstract}
The process of transformation is inevitable in all areas of economic and social life, as well as in banking. Accordingly, the transformation process has not bypassed our country. The dynamics and pace of transformation depends on the level of development of the country and developments in the world economy and politics. In the last decade, the events in the global financial market, aimed at profit maximization at any price (without analysis and appreciation of the risks involved), led to the global economic crisis in late 2007. This is slowing down the process of transformation of the banking sector in Serbia, since it depends on the credit and development capacities of the clients and the overall socio-political situation in the country. Domestic banks are organized in a modern way, in compliance with the recommendations of the EU and the rules of the Basel agreement; they have electronic equipment and most professional staff. The strengthening of competition in the domestic market will deepen the differences between banks and provide space for consolidating the domestic banks through the process of mergers, acquisitions and privatization. Moreover, the aspects of faster capital strengthening, which carry other advantages of the organizational, technical and technological nature, may faciliate costeffective operations and more efficient use of resources.
\end{abstract}

Key words: Serbia, European Union, banking sector, banks, transformation, transition.

Received August $11^{\text {th }}, 2016 /$ Accepted December $27^{\text {th }}, 2016$

Corresponding author: Miloš Pavlović

Univerity of Priština, Faculty of Economics, Kosovska Mitrovica, Republic of Serbia

E-mail: milos.pavlovic@pr.ac.rs 


\section{INTRODUCTION}

The process of transition has spread over the developed and less developed countries and all areas of economic and social life. Today, due to large and unexpected losses in the previous century and the unwillingness of participants in the financial markets, there is a need for a more serious approach to risk management in the financial operations. The Basel Committee formulated the general rules and standards on banking supervision and proposed examples of the best banking practices. Therefore, the Basel Committee on Banking Supervision (BCBS) encourages all Member States to respect the general business principles and standards without direct attempts to harmonize techniques used by supervisory authorities.

The decisions taken by the Basel Committee represent the commitment for many other countries outside the framework of the G-10, which contains the representatives of other countries. These decisions relate to different financial authorities in one of the most important areas pertaining to the reconciliation of the differences that exist in the international framework of banking supervision, for the purpose of ensuring the application of two basic principles: that there is no internationally active bank which can escape supervision, and that the process of control be adequate. In 1988, the Basel Committee decided to introduce a system for measuring the adequacy of international capital standards, known as the Basel I Agreement. Basel I standards were related to minimum amount of capital, with banks holding required capital amounting to at least $8 \%$ of risk-weighted assets. Based on extensive cooperation with banks and other financial institutions, on $26^{\text {th }}$ June 2004, the Basel Committee released a new Capital Accord, known as Basel II. This paper presents a new set of standards for establishing minimum capital adequacy ratio for banks. ${ }^{1}$

Basel II is an upgrade to the 1988 Basel I agreement insofar as it takes the basic infrastructure to calculate the level of capital required, by increasing the sensitivity of the risks to which the bank is exposed. This is primarily achieved through closer harmonization of capital requirements to the risk of losses in the individual placement, and by introducing a new requirement for allocating capital for exposure to risk, which is caused by defects in daily bank operations (operational risk). In addition, the main novelty of Basel II relates to the introduction of new activities that build on the requirements for a minimum level of capital that refers to the function of control (supervision) and market discipline, which encourages the improvement of risk management. The new Basel Agreement includes three pillars, which should jointly contribute to increasing the overall stability and security of the financial system. The first pillar is tasked to significantly improve the methodology for determining the minimum capital adequacy ratio, while the second and the third pillar introduce innovation in the process of supervision of bank operations.

The first pillar of the new Basel Agreement defines the modalities for determining the minimum amount of capital that each individual bank must have in order to be able to adjust that amount of the actual level of risk of economic losses which the bank is exposed to. The coefficient of the capital adequacy ratio shall not be less than $8 \%$.

The second pillar of the new Basel Agreement is the Supervisory Review Process, which is based on a series of guidelines that indicate the necessity for banks to assess their capital adequacy in relation to the overall risks which they are exposed to, as well as the need for the competent authorities to carry out a review of these processes and implement

${ }^{1}$ BCBS, (2001) The New Basel Capital Accord, Basel Committee on Banking Supervision, Basel. 
specific measures in response to the adequacy of the assessment methods. This means that the supervisory review process is not aimed only at ensuring capital adequacy that ensures risk-taking by banks but also at motivating banks to develop and use techniques perfected in the process of risk management of the bank.

The third pillar - Information that will be disclosed by the bank should be consistent with the way the bank management evaluates and manages its risk. Disclosure of particular sets of business data should provide more effective public information on the types and extent of risk to which the bank is exposed, and enable concerted and clear basis for comparison, which will result in a more advanced system of risk management and greater security in the financial market. In the European Union, there are_ongoing activities aimed at a stronger implementation of Basel II and rounding off the single market for financial services mainly through the unification of the legal rules.

Basel III is a response of the Committee to the global financial crisis that escalated in 2008. First of all, the document is an effort to make the regulatory framework of the banking business stable, while stressing the importance of the adequately risk management methods. The main aim of Basel III is to provide conditions in which banks are able to absorb any shocks that occur in the financial markets or in the economic sectors. The document was agreed upon in 2010, with a clause that the implementation would start from 2013.

Basel III standards combine two complementary approaches to supervision: microlevel approach at the level of individual banks (on the one hand), and macro-level approach (on the other hand). Micro-prudential supervision refers to the increasing resistance of banks in periods of market uncertainty, through conditionality higher quality of bank capital, more appropriate risk capture and adequate supervision. On the other hand, the macro-prudential supervision emphasizes three elements:

- Capital shock absorbers;

- Liquidity standards;

- Leverage ratio.

In the context of a new agreement, we can talk about the changes of the concept of capital. Minimum requirements for capital still amount to $8 \%$ of risk of the weighted assets, while the minimum amount for the first lawyer of capital structure is $6 \%$. In relation to Basel II, the changes are reflected in the elimination of the third layer of the capital structure, rearrangement of the layers 1 and 2 and the introduction of new categories, such as protective and countercyclical shock absorbers. The justification for the inclusion of capital protection absorbers is the creation of inventories in the expansion phase, which would be used in case of loss, without any consequences for the minimum required rate of capital. Shock capital is included in the layer 1, namely the common equity, but should be set at $2.5 \%$ above the minimum required capital. In this way, the minimum requirements are increased and amounted to $8.5 \%$, when it comes to layer 1 capital, or $10.5 \%$ of total capital. Obligation is not directly imposed on banks to form counter-cyclical shock absorber but, depending on the nature of threats to the system, national regulators may require this form of capital. The essence of counter-cyclical shock absorber is reflected in the fact that systemic risk increases with a large credit growth, while its scope is within the range of 0 $2.5 \%$ of risk-weighted assets. Validity of the second pillar of Basel III is reflected in the fact that the problems originated due to the lack of liquidity in spite of capital adequacy. One of the standards related to the second pillar of this document requires the obligation of holding highly liquid assets in an amount greater than the expected net cash outflows over 
the next 30 days. As the third pillar, leverage ratio contributes to establishing the limits of total exposure of banks and eliminating the possibility of overindebtedness of the bank. Deadlines for the planned implementation vary, depending on the specific element of the Agreement. When it comes to the minimum requirement for capital, the implementation was planned to be completed by $1^{\text {st }}$ January 2015 . Also, the implementation of standards related to protection and counter-cyclical shock absorber was planned to begin on $1^{\text {st }}$ January 2016 and to extend until the $1^{\text {st }}$ January 2019 , due to the need to meet the required standards until $1^{\text {st }}$ January 2019 . When it comes to standards of liquidity, it is important to note that the observation phase began in 2011 and it was planned that in 2015 the liquidity coverage ratio would be in operational use. Implementing provisions relating to the leverage ratio began in 2011 and it was planned to ensue in two phases: the monitoring phase (until $1^{\text {st }}$ January 2013) and the parallel application phase.

\section{THE BANKING SECTOR OF THE EUROPEAN UNION}

In the last three decades of the $20^{\text {th }}$ century, the banking sector in the European Union went through a number of changes, which influenced the changes in the structure of the banking system and the activities of banking institutions. The global economic crisis, which escalated in the United States and rapidly transferred to other world economy, caused the problem in banking business. Measures of the authorized institutions were aimed at providing the necessary resources and preserving the stability of the banking sector, because the problems were manifested through a lack of liquidity and bankruptcy of banking institutions. In the European countries, there are different systems of regulation at the level of each Member State. However, despite the differences between the observed banking sectors, the banking regulation systems_contain certain common features.

As in the pre-crisis period, banks were the main institutions of external financing of companies in the EU financial system, which is described as a bank-centric (Allen, Carletti, 2008). However, in recent years the banking sector in the European Union is facing a number of changes in the structure, which are primarily the result of a higher level of economic integration.

During the 1970s and 1980s, there was a significant step towards the regulation of the banking business in the context of the former European Economic Community, the adoption of two banking directives (the First Banking Directive and the Second Banking Directive). The First Banking Directive outlined the obligations of the host country (the host country rule), according to which the banks permitted to do business in foreign countries if they have the permission of the national regulator of the host country. The Second Banking Directive established the principle of control of the home country (the home country rule), according to which the national regulatory authority is responsible for the activities of the national bank, regardless of the country in which it operates. Upon the creation of the European Monetary Union (EMU), European Central Bank (ECB) has become the central institution, which conducts a single monetary policy. In addition to the ECB, the national central banks of the EMU countries have an important role in the regulation of banking institutions as they are obliged to submit information to the ECB.

The problems are reflected in the lack of integration of the member states, as well as the differences in legal and tax terms which impeded integration in the EU. In 2001, the Lamfalussy committee proposed a set of measures, embodied in the four-level approach: 
- Level 1 - the creation of a framework for adopting the proposal directives and regulations.

- Level 2 - preparing a set of measures for implementation; in this process, the European Commission closely cooperates with the following four committees: the European Banking Committee, the European Securities Committee, the Insurance and Pension Committee, and the Committee of financial conglomerates.

- Level 3 - harmonization of the national regulatory framework and supervision between countries at the EU level; this will be achieved through further consultation with the expert committees such as the Committee of European Banking Supervisors, the Committee of European Securities Regulators, and the Committee of European Banking Insurance and Pensions.

- Level 4 - implementation of harmonized legislation and measures; the European Commission takes into account the process of implementation of the rules in the Member States and may impose sanctions for failure to implement them (Mülbert, Wilhelm, 2011: 187-232).

In the territory of the European Union, the standards of the Basel Committee related to capital are given in the form of directives or regulations. Until today, the Basel Committee for banking supervision has verified three significant documents relating to banking regulation. The first Basel document was aimed at establishing uniform requirements in terms of the amount of capital that banks are required to hold. The objectives of this document were: to prevent banking crises, to present domestic banks as stable and solvent, and to eliminate problems arising from regulatory non-conformities. The standards of Basel III in the EU have been implemented in the form of a directive on capital requirements (Capital Requirements Directive IV - CRD IV). Regarding the implementation, the CRD IV differs from the original text of the Agreement. Also, despite the fact that the Basel Capital Accord (Basel I) was a framework for banks facing international business, the EU legislation made no distinction among banks because of the potential of large distortions in financial markets. Therefore, the standards of the Basel III in the EU were based on the principle of the "one measure for all". Regarding the CRD IV, there are the following differences from the original text of the Basel III:

- CRD IV gives more attention to corporate governance arrangements whereby the Executive Committee shall have a greater role in the risk management process.

- Member states supervisors penalize banks if they violate the provisions of CRD IV rules adopted by the European Banking Authority.

- Banks are required to submit annual reviews of their activities to supervisors.

- The institutional framework enables a turn in used rating systems, whereby banks are required to develop internal rating systems (Schmidt, Kern, Benink, Lastra, Wihlborg, 2011:125-193).

The global financial crisis has shaken the entire EU and, thereby, exposed the weaknesses of the existing regulatory framework. Therefore, the aim was to remove and rectify the observed drawbacks. To that effect, the European Commission established a working group whose task was to draw attention to the necessary changes in the EU regulatory framework. The basic disadvantages were: a lack of prudential supervision, an inefficient mechanism for early warning, and a lack of efficiency of the committee functioning within a third-level Lamfalussy procedure. Bearing in mind all the drawbacks, the proposed framework of supervision in the EU is based on two interconnected pillars: 
- Pillar I - Macroprudential supervision, which is formed by the European Committee for Systemic Risk Board (ESRB), whose main tasks are to prevent and mitigate the risks that threaten to reduce the stability of the EU financial system, on the one hand, and to provide conditions for the smooth functioning of the EU market, on the other hand.

- Pillar II - Microprudental supervision, which is established in the European System of Financial Supervisors (ESFS), which includes the national supervisory authorities and the European Systemic Risk Board. One of the important novelties is the establishment of the European supervisory authorities in banking, securities and insurance and pension funds, and the formation of the Joint Committee. These bodies were replaced by the CEBS, CESR and CEIOPS committees that were operating within the framework of the third-level Lamfalussy procedure (Kidwell, Blackwell, Whidbee, Peterson, 2008).

The European Committee for Systemic Risk Board (ESRB) functions as a mechanism for early warning, including the option to propose action for risk control if necessary. When pertaining to specific member states, warnings may be either general or subjectspecific. However, the ESRB does not have legally binding powers; all proposals are mainly given in the form of recommendations which may affect the efficiency of the system. In such circumstances, national supervisors can do what they consider necessary, not what the ESRB has recommended. On the other hand, supervisory institutions operate under the auspices of the ESFS, including both national financial supervisors and three EU supervisory institutions: the European Banking Authority (EBA), the European Directorate for Insurance and Pension Funds (EIOPA), and the European Directorate for the Securities market (ESMA). The European Commission has chosen the model of regulation that involves the separation of the banking, insurance and securities markets. However, the model enables cross-sector operations in order to establish integrated regulatory principles.

Due to the consequences of the global economic crisis, some European Union countries face the problem of growing public debts. These problems have affected the entire banking system in the EU, especially those banks that had assets in the form of securities issued by the states which had encountered financial problems in the public sector (such as: Greece, Italy, Portugal, Spain and Ireland). The reason for the spill-over effects of the crisis is the high degree of integration of the banking system, on the one side, and the real sector of the Member States, on the other side, which was confirmed by the conditions of economic recession and rising public debt, when banks had to face reduced citizens' confidence in the banking system.

In September 2012, the European Commission issued a proposal related to the creation of a single supervisory mechanism (SSM) and more specific regulation of the role of European Banking Authority (EBA). The role of the supervisor was assigned to the European Central Bank (ECB), which was to start performing its supervisory function in 2014. The focal point of this supervisory institution are banks which have already sought help from foreign banks and banks which were already in the process of recapitalization. Although the ECB is in the center of the system, as the main supervisory institution, the national central banks (NCBs) remain in charge of supervising banks in their countries. Therefore, in order to provide for an efficient operation of the banking system, it is necessary to facilitate the coordination of actions of the ECB and the national central banks. 
In addition to benefits, the formation of a banking union implies certain costs, which are inter alia reflected in developing adequate human resources solutions. Due to fact that the new infrastructure requires high quality and well-trained staff, there are considerations in that direction as well.

\section{THE BANKING SECTOR OF THE REPUBLIC OF SERBIA}

In Serbia, there is a natural interdependence between the development of the banking sector, the socio-political situation and economic changes. In Serbia, the transition period started in 1992 but the most significant changes took place after the political changes in 2000, when conditions were created for foreign investments. The beginning of the transition period was marked by a variety of turbulences but the banking sector experienced the fastest growth. The legislation was aimed at supporting the development of domestic banking and adapting the banking sector to contemporary trends.

The essence of transformation processes are changes in the way of thinking, business practices, decision-making processes, and activities of all subjects of social and economic life. Transformation of banks involves changes in the mode of organization, management, finance, property relations, human resource management, and introducing new technologies. All of these changes are aimed at providing for more efficient operations, the creation of highquality banking products, meeting the needs, demands and desires of the consumers of banking services, raising the level of services or products, and attaining higher profits.

Only transformations implemented at all levels will contribute to a faster development of the market economy and increase the level of competition. The transformation of the domestic banking system implies restrictive monetary policy by the central bank, increasing the level of independence of the central bank, introducing hard budget constraints by the state, rehabilitation of the banking system, bank privatization, opening the market for the entry of foreign banks and other financial institutions. The aforesaid process ensues alongside with the development of financial markets in transition countries. The commitment to market-oriented economy means improving the management functions at the level of banks, contributing to an adequate analysis of credit and risk, introducing internal quality control, proper management and monitoring of assets and liabilities.

Serbia recorded a positive financial result until the end of 2008, when the effects of the global economic crisis started affecting the economy. The profit of the banking sector amounted to 34.9 billion dinars (eight banks were operating at a loss). Domestic banks are well capitalized, which enabled the National Bank of Serbia (NBS) to encounter the first and second wave of the global economic crisis by taking some proactive measures. On 31 December 2008, the total capital of the banking sector amounted to 4,879 million Euros, and the capital adequacy ratio was $23 \%$. If the budget coefficient was calculated in accordance with Basel II, it would amount to about 19\% (according to the NBS calculations), which would be significantly higher than in the EU countries (where the average is $8 \%$ to $10 \%$ ) and in the neighboring countries in the region $(15 \%){ }^{2}$ In the previous year (2007), there was a high rate of collection of the disbursed loans. Also, the level of reserved funds indicates that banks either did not adequately classify their loans or did not implement an appropriate percentage of reserved funds to a specific placement. During 2008, the level

\footnotetext{
${ }^{2}$ Source: The National Bank of the Republic of Serbia; www.nbs.rs
} 
of non-payment of due claims (billing) in the segment of the population was $1.5 \%$, while the level of non-payment of claims in the segment of legal entities amounted to $6.3 \%$. It should be noted that, in the previous period, commercial banks mostly "played" with the level of reserved funds; namely, they disposed of them in order to show better business results. On $31^{\text {st }}$ December 2008, the companies accumulated amount of external debt of about 11.5 billion Euros, which is an increase of $350 \%$ over a period of three years. It is important to mention that the level of the disbursed residential loans, as compared to the increase of the domestic gross product $(2,9 \%)$, shows that Serbia was in an early phase of transition of the financial sector (considering that this percentage is about $50 \%$ in the EU). Domestic banks faced many problems: lack of knowledge of processes and banking technologies, inefficient management, quality of the management team and the leadership, necessary additional management skills, and increasing the level of risk. ${ }^{3}$

The key issues for the efficient management of local banks are: the ability to change the management, strategic planning and strategic management approach, flexible organizational structure and strong marketing orientation. In 2009, the level of loans in use was on the slight rise, both in terms of the general population and the corporate world, thanks to the stimulating and proactive measures of the NBS aimed at supporting the bank lending activities and relaxing the clients who encountered problems in repaying their loans. However, the economy and population faced reduced liquidity as a result of the manner of financing in the previous years. By 7th April 2009, banks approved a total of 170 million Euros of subsidized loans. Banca Intesa was a leader in this trend; in the first quarter of 2009, it placed 112 million of loans from the subsidized lines (the largest part of which came from its own refinanced portfolio). Banca Intesa was successfully followed by the Commercial Bank, Belgrade. It should be noted that the credit arrangement with the IMF was concluded for a period of three years, and repayment was envisaged to take place in a single consignment, upon the expiry of the loan period. The major question is how and from which resources Serbia will repay all these loans.

By $31^{\text {st }}$ December 2008, the Serbian banking sector kept a low foreign currency exchange risk ratio of just $8 \%$ (which is much lower than $14.7 \%$ in 2007) at domestic money market. In the first wave of the crisis, domestic commercial banks were in need to preserve liquidity; so, they used the free funds placed in repo with the National Bank of Serbia. Liquidity indicators shows that most banks had the same level of exchange risk (between 1.5 and 2.5), which should confirm the satisfactory level of liquidity. Since October 2008, the trends of active and passive interest rates have been determined by the liquidity of banks. Problems with liquidity increased the importance of the domestic money market. Taking into account the developments in the global and domestic financial markets, in the next period banks should focus on the collection of their receivables (extended loans) or the restructuring of placements, which there is a problem of billing, due to the constant growth of the clients' tardiness throughout the year (on $30^{\text {th }}$ November 2009 , it was $9.7 \%$ in the segment of legal entities, and $3.9 \%$ in the retail segment). ${ }^{4}$

The level of efficient business is quite low, due to the high structural imbalance between banks in terms of financial strength and operations results. Strengthening competition in the domestic market will make these differences more visible. It is important to create a development bank, which will take the role of the Development Fund of the

\footnotetext{
${ }^{3}$ Source: The Association of Serbian Banks (ASB); www.ubs-asb.com

${ }^{4}$ The Association of Serbian Banks (ASB); www.ubs-asb.com
} 
Republic of Serbia with an assignment to contribute to the economy and provide adequate financial transactions on the market. Past experience shows that the state is helping the banks, not the economy. Banks used subsidized credit lines for refinancing their own loans to legal entities. Thus, banks ensured that their credit ratings were not downgrade; they provided favorable loans for themselves and for their clients, they closed down the existing credit obligation on time, and prolonged the problem of debt payment to the next calendar year.

\section{CONCLUSION}

The global economic crisis has exposed the weaknesses of the banking regulation system, which have been particularly prominent in the area of banking regulation goals. The impossibility of their fulfillment is a result of inadequate implementation of financial instruments, high financial leverage, gaps and inconsistencies of the risk management system, and high interdependence of financial entities in terms of exposure to systemic risk. An additional problem has been created by the inappropriateness of the instrumental system of bank regulation in specific situations. It is important to note that the developed instruments are not standardized in terms of time and space, which is not relevant to all banking regulation systems, but may be used depending on the specific situation. However, there are certain similarities between some developed systems of banking regulation, such as: Japan and the UK, for example, as each of these countries has a single regulatory authority.

In this paper, we first discussed the issues relevant for banking regulation systems, which have become topical in conditions of the global financial crisis. Due to the fact that the problem of asymmetric information is present in all systems of banking regulation, it is necessary to establish the monitoring of the banking activities. In addition, the role of central banks (as the last instance creditor/ lender) should be considered as an additional regulation mechanism, due to possible adverse effects on the efficiency of the system. Finally, deposit insurance system, as an important element of the system of banking regulation, can be organized in several ways, depending on the specific situation.

While observing the development of banking regulations in a historical context, we also examined the features of the system of banking regulation in the EU and in Serbia. On the territory of the EU, where the financial system is characterized as a bank-centric system, efforts have been made to integrate and harmonize the regulatory frameworks of different countries. The problems of insufficient harmonization of the regulatory framework and the lack of integration of financial markets are manifested in conditions of high political integration. Therefore, special efforts have been exerted to create uniform standards and procedures, and integrated financial markets, where the FSAP and Lamfalussy procedures play an important role (Talani, 2009). On the other hand, the development of banking regulation in the territory of Serbia is characterized by overall national and global developments. Analyzing the results of the questionnaire on the implementation of the Basel II agreement by commercial banks in Serbia, it can be concluded that the following problems occurred in the implementation: the high costs of training staff and building information systems, technology improvement, the development of models and databases, and lack of staff. In the future, we should follow the steps necessary to integrate Serbia into the single EU financial services market. If we want to be integrated into the single market, it is very important to be consistent in implementing and applying the envisaged 
standards. It should be noted that the integration of financial markets is a key factor in the development and modernization of the entire Serbian financial system and economy as a whole. It is realistic to expect that this project will be implemented in phases, according to the dynamics of envisaged steps for Serbia's EU accession and the EU Directives in the field of finance and banking.

The Basel Committee on Banking Supervision has an important place in the development of banking regulation. As a response of to the regulatory issues, thus far, the Basel Committee has published three documents important for the banking regulation. The main aims of the Basel I Agreement were to prevent banking crises and to establish uniform requirements in terms of the capital amount and integration regulations. However, subsequent development trends created the need to revise this document and rectify its shortcomings by focusing on the credit risk and the inability of portfolio diversification. The publication of the Basel II standards solved the above problems, but their inadequacy was proven in the circumstances of the global economic crisis. Today, efforts have been made towards the implementation of the Basel III standards, which represent the regulator's response to the problems raised by the global economic crisis ${ }^{5}$. Under the influence of the global economic crisis, the weaknesses of the banking sector are in the foreground. In the area of the EU, solutions include two approaches to supervision: macro-level approach, which underscores the importance of systemic risk and its regulation, and micro-level approach aimed at coordinating regulatory activity in certain segments of the financial system (Chang, 2009). In this context, it is important to establish institutions such as the European Systemic Risk Board (ESRB) and the European System of Financial Supervisors (ESFS); along with other financial institutions, they are the institutional framework of the new system of banking regulation. A significant issue is the formation of the banking union in the European Monetary Union (EMU) (Allen, Carletti, 2008). The key arguments in favor of establishing the EU banking union are that it would contribute to the efficient functioning of the monetary union, the growth of credit indebtedness and the growing trust, but it is important to include all types of banks. The Council for Supervision of Financial Stability was established to identify, control and regulate the systemic risk, in which context it is important to emphasize the accountability and recomposition of regulatory institutions (Franklin, Gale, (2007). The global economic crisis has led to a shift in the mode of regulation of the banking system. In the conditions of the global economic crisis, the above indicates that the differences between the EU system of banking regulation and the Serbian banking regulation system have been significantly decreased since Serbia embarked on the process of approaching and joining the EU.

\section{REFERENCES}

1. Allen, F., Carletti, E. (2008). The Roles of Banks in Financial Systems. University of Pennsylvania and University of Frankfurt and CFS.

2. BCBS, (2001). The New Basel Capital Accord, Basel Committee on Banking Supervision, Basel.

3. BCBS, (2009). History of the Basel Committee and its Membership, Basel Committee on Banking Supervision, Basel.

4. Chang, M. (2009). Monetary integration in the European Union, Palgrave Macmillan, New York.

5. Franklin, A., Gale, D. (2007). Understanding Financial Crises, Oxford University Press, New York

${ }^{5}$ BCBS, (2009) History of the Basel Committee and its Membership, Basel Committee on Banking Supervision, Basel. 
6. Kidwell S. D., Blackwell W. D., Whidbee A. D., Peterson L. R., (2008). Financial Institutions, Markets and Money, John Wiley \& Sons, 10th Edition

7. Mülbert P., O., Wilhelm A., (2011). Reforms of EU Banking and Securities Regulation after the Financial Crisis, Banking \& Finance Law Review, 26(2011), 187-232.

8. Schmidt R. H., Kern A., Benink H., Lastra R. \& Wihlborg C., (2011). 'The Recent Financial Crisis: Lessons from Europe', in Litan R. (ed.), WORLD IN CRISIS: Insights from Six Shadow Financial Regulatory Committees from Around the World, FIC press, pp. 125-193.

9. Talani, L. S. (2009) The Future of EU, Palgrave Macmillan, New York

10. Djurovic-Todorovic J., Djordjevic M., Siljkovic B., (2010), Monetary policy of the European central bank and National bank of Serbia in function of stabilisation of economy in the conditions of global financial crisis, Thematic Proceedings of Economic Policy of Serbia in 2010 - towards a new model of macroeconomic stability, NDES and the Faculty of Economics in Belgrade.

11. Narodna banka Srbije (National Bank of Serbia); www.nbs.rs

12. Udruženje banaka Srbije (Association of Serbian Banks); www.ubs-asb.com

13. The G20 website; www.g20.org

\section{REGULATIVA EVROPSKE UNIJE I BANKARSKI SEKTOR REPUBLIKE SRBIJE}

Proces transformacije je neminovan u svim oblastima privrednog i društvenog života, pa tako $i$ u bankarstvu. Shodno tome, proces transformacije nije zaobišao ni našu zemlju. Dinamika $i$ tempo transformacije zavisi od nivoa razvijenosti same zemlje i dešavanja u svetskoj ekonomiji i politici. Poznato je da su dešavanja na svetskom finansijskom tržištu u protekloj deceniji, usmerena na uvećanje profita po svaku cenu (bez analize i uvažavanja prisutnih rizika), doveli do svetske ekonomske krizu krajem 2007. godine. To je usporavalo proces transformacije bankarskog sektora u Srbiji, s obzirom da on zavisi od kreditne $i$ razvojne sposobnosti svojih klijenata $i$ društveno-političkih prilika $u$ zemlji. Domaće banke su organizovane na savremen način, uređene po ugledu na EU i pravila Bazelskog sporazuma, i raspolažu elektronskom opremom i uglavnom profesionalnim kadrom. Takođe, jačanjem konkurencije na domaćem tržištu će produbiti razlike između banaka i dati prostor za ukupnjavanje domaćih banaka kroz proces spajanja, pripajanja i privatizacije, kao vidova bržeg kapitalnog jačanja, koji nose $i$ druge prednosti organizacione $i$ tehničko-tehnološke prirode, a olakšavaju put do ekonomičnijeg poslovanja i efikasnije upotrebe sredstava.

Ključne reči: Srbija, Evropska Unija, bankarski sektor, banke, transformacija, tranzicija. 